\title{
INTERNOVA E-LEARNING PLATFORM IN AN ENTREPRENEURIAL CONTEXT
}

\author{
Isabel Araújo ${ }^{1,2}$, Rita Pinheiro ${ }^{1,3,4}$, Pedro Miguel Faria ${ }^{1}$, João Nuno Azevedo ${ }^{1}$, \\ Sónia Faria ${ }^{1}$ and Manuela Vaz Velho ${ }^{1,4}$ \\ ${ }^{1}$ Instituto Politécnico de Viana do Castelo, Viana do Castelo, Portugal \\ ${ }^{2}$ Centre for Studies in Education and Innovation (CI\&DEI), Instituto Politécnico de Viseu, Portugal \\ ${ }^{3}$ Centro de Engenharia Biológica (CEB), Universidade do Minho, Portugal \\ ${ }^{4}$ Centro de Investigação e Desenvolvimento em Sistemas Agroalimentares e Sustentabilidade (CISAS), \\ Instituto Politécnico de Viana do Castelo, Portugal
}

\begin{abstract}
Currently, there is still an opposition of teachers to the implementation of new technologies in an educational context. Although several studies point out the relevance of the use of information and communication technologies in pedagogical practices, providing educational contexts more focused on learning practices and fostering more active and autonomous professionals. In this context, this article emphasizes the purpose of using Information and Communication Technologies (ICT), as well as virtual learning environments, in the higher education system, to support the teaching-learning processes. In this article, a state of the art was carried out, in order to demonstrate some advantages of the teaching-learning process, the teacher's and student behaviour profiles and its role in relation to the use of new technologies. The objective of this study was to analyse the impact of using a digital platform on the teaching-learning process in an educational context. An e-learning digital platform, INTERNOVA, developed within the scope of the INTERNOVAMARKET-FOOD project (0437_internovamarket-food_1_E - Internovamarket accelerator program to increase the competitiveness of the food sector in Galicia-Northern), within the curricular unit of Food Safety and Certification of the Master in Food Engineering's curriculum. In order to assess the impact of the training course on the students' learning outcomes, a survey was applied to master's students and Food Engineering research fellows (participants). The same survey was applied before the training and after it in order to compare both results. At the end of each training course, another survey was addressed to all the participants asking about the organization, quality and the easiness of the platform. The results obtained show that the students had no difficulties in using the platform, having revealed that they would like to continue using it more frequently. The data obtained are an evidence of the participants' learning improvement and their involvement in the learning process through the INTERNOVA platform. With this work, it can be concluded that the ICT applied to a curricular program can be a very important support in the teaching-learning process. In this context, it is important to recommend well-designed curricular programs so that teachers can improve their teaching practices, enhancing students' digital skills, and thus contributing to the development of more active and autonomous professionals.
\end{abstract}

\section{KEYWORDS}

E-learning Digital Platform, ICT, LMS, Virtual Learning Environments, Higher Education, Engineering Teaching

\section{INTRODUCTION}

As a result of technological developments, namely in higher education system, the use of Information and Communication Technologies (ICT) in the educational context has constantly increasing (Daniela et al, 2019), which has led to changes in teaching and learning processes. The evolution of ICT facilitates the access of information by the majority of the population, promoting deep changes in several areas of knowledge, mainly in the academic field, where it is discussed and built knowledge. However, the teaching and learning processes in higher education system have not been able to keep up with the fast-technological development.

In his work, Moran (2007) stated that many conventional classes were outdated, in which the method adopted was only expository and the student was merely a receiver of knowledge. Furthermore, he warned that the fundamental issue in education does not depend only on technologies. In this sense, several studies were 
carried out in order to try to understand the impact of ICT in the teaching and learning processes (Nortvig et al, 2018, Araújo \& Faria, 2019).

Current students, born in the digital generation, show more technological skills, compared to their teachers, who are still somewhat reluctant to use ICT in an educational context, particularly in the use of learning platforms.

In this article, it was demonstrated the experience and the results obtained by implementing an e-learning platform in a higher educational context, within the curricular unit of Food Safety and Certification of the Master in Food Engineering. The e-learning platform was developed as part of the Internovamarket-food project for training of employees of companies in the agri-food sector.

\section{ICT IN THE TEACHING-LEARNING PROCESS}

Several studies point out the advantages of using ICT in an educational context (Al-Samarraie et al, 2018; Nortvig et al, 2018, Cidral et al, 2018; Araújo \& Faria, 2019). These technologies, in addition to enabling access to information, are valuable tools in the development of new methods of learning and support new contexts for the corresponding learnings (Dias, 2004). Furthermore, citing Daniela, Strods \& Kalnina (2019: 12), "On the one hand, there is the conviction that technologies are indispensable, both for improving learning and for making learning process more effective, both in terms of learning outcomes and in terms of costs. Additionally, technology and technological solutions can provide sustainability of knowledge because students develop the competences that they will need in their future professional work".

Such technologies facilitate the development of virtual learning environments, enhancing spaces for the construction of knowledge, and thus are an asset for the teaching and learning processes (Junior \& Coutinho, 2010). Consequently, they can change the way students acquire, use and build knowledge (Trinder et al, 2008), promoting new forms of learning. In this context, the traditional teacher, who transmits knowledge, starts to have the role of advisor and facilitator of learning (Araújo, 2014), playing a crucial role in creating and sustaining conditions for the (co) construction of knowledge. The passive student, the recipient of knowledge, takes on a more active role in the construction of knowledge, self-managing his learning process.

In fact, ICT provide diversified access to information, and students can interact with digital subjects and also communicate synchronously or asynchronously with other users. However, it is not technologies themselves that improve teaching or students' learning, ICT allows that teachers and students can work together in a way that traditional teaching methods did not permit, bringing substantial advantages for teachers and students (Dias \& Diniz, 2010).

Several studies reflect the impact of ICT on learning environments, concluding that these environments can be a space full of meaning, where human beings and technical objects interact, enhancing the construction of knowledge (Ribeiro, 2010).

The adoption of learning environments, supported by platforms to support face-to-face, distance or mixed educational processes is growing. According to Coutinho \& Bottentuit (2007), in terms of functionalities, e-learning platforms should allow the availability and access to pedagogical content, communication/interaction between teachers and students and mechanisms for the evaluation and management of teaching/learning processes.

According to the literature, in these environments the students stop being so dependent on the teacher, assuming greater responsibility for his own learning, becoming more active, more autonomous and having greater freedom to plan his learning activities.

However, according to Marchiori et al. (2011) the performance of higher education students depends on the attention they dedicate to their studies, which consequently has implications to learning success. The use of technologies in higher education system facilitates access to information, but it is necessary for the teacher to teach students to turn this information into knowledge (O'Donnell \& Sharp, 2012). 


\section{THE INTERNOVA PLATFORM}

The INTERNOVA platform (Figure 1) was developed within the Internovamarket-food project (0437_internovamarket-food_1_E - Internovamarket accelerator program to increase the competitiveness of the agro-food sector in Galicia-Northern Portugal (Financial support: Portugal Interreg V-A Spain-Portugal (POCTEP) 2014-2020, in axis 2 "Integration of growth through cross-border cooperation in favour of business competitiveness"), with the primary objective of providing training to employees of agri-food companies in the North of Portugal and Spain.

This platform offers two training courses: a) International Featured Standard (IFS) Food \& BRC Global Standard for Food Safety, b) ISO 22000:2018 - Food Safety Management System (ISO22000) (Figure 1). The contents of each of the two training courses were divided into several modules. Each module has a learning component and a component for assessing what was learned by the students/trainees. The evaluation component consists of a set of questions related to the respective modules' contents. The students/trainees can only access the next module after obtaining approval (success) on the previous one.

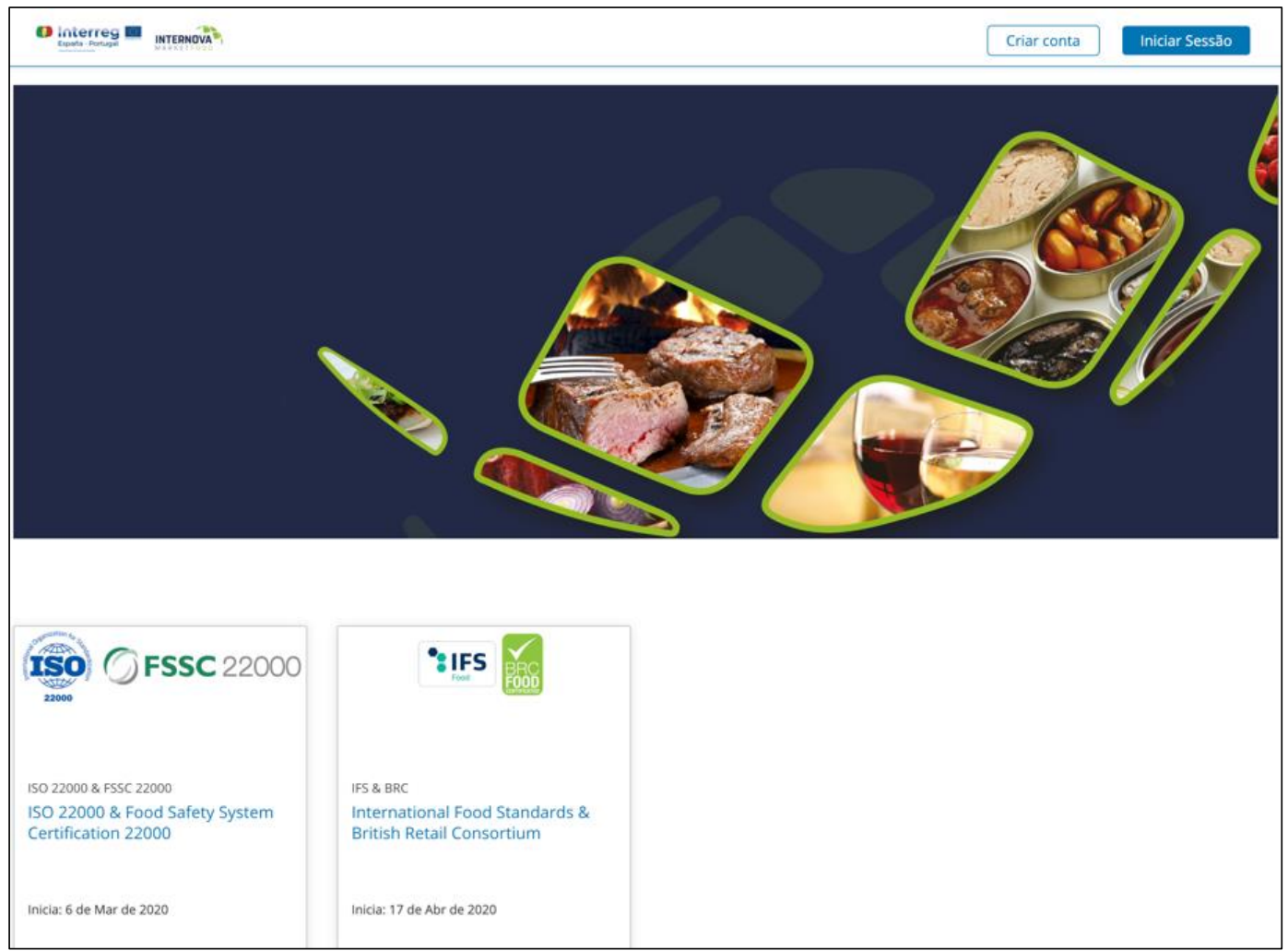

Figure 1. The INTERNOVA platform

For a student/trainee to be able to attend the course it is mandatory to make the registration in the platform (account creation). The contents of the modules are available in an audio-visual format. The training videos available provide trainees with all the information necessary to carry out the assessment tests. The trainees, after having successfully completed all modules, are automatically given a Certificate of achievement, by the platform. 


\section{METHOLOGY}

The Food Safety and Certification curricular unit is part of the 1st year of the Master in Food Engineering's curriculum at the Higher School of Technology and Management of the Polytechnic Institute of Viana do Castelo (ESTG-IPVC).

The INTERNOVA platform offers two training courses: a) International Featured Standard (IFS) Food \& BRC Global Standard for Food Safety, b) ISO 22000:2018 - Food Safety Management System (ISO22000). These two training courses contain the contents that are part of the Food Safety and Certification's curriculum. The study took place at the beginning of the 2nd semester of the academic year of 2019/2020. This study was attended by 11 master students (MEA1 to MEA11) and 6 food engineering research fellows (Scholarship1 to Scholarship6) from the Food Engineering Group of ESTG-IPVC. In order to study the use of the INTERNOVA platform in an educational context, the students and the research fellows were asked to register in the platform (create an account). Then the participants were requested to take the course on a non-face-to-face basis, that is, online. The period available for each training course was 30 days.

In order to assess the impact of the training course on the students' learning outcomes a survey was applied to students/research fellows. The same survey was applied before the training and after it in order to compare both results. At the end of each training course, another survey was addressed to all the participants asking about the organization and the easiness of the platform and the training course. A link with the survey was send through email. The survey had 10 questions related to the easiness of the platform, two questions related to the tasks available and two other questions related to the global assessment of the platform and its contents, in order to assess the satisfaction degree of the trainees.

The System Usability Scale (SUS) is an evaluation model used by Brooke (1986), as it is considered one of the most accepted for its reliability and validity. It contains a simple scale of ten items related to usability, allowing the assessment of subjective perceptions. It uses the Likert scale with values ranging from 1 (strongly disagree) to 5 (strongly agree), with 3 meaning neutral. In addition, the survey contains 4 extra questions to better assess the platform's purpose in an educational context. The survey was made available on an online platform and subsequently a descriptive statistical analysis was carried out and also a SUS analysis which encompasses five quality components: ease of learning, efficiency, ease of memorization, minimization of errors and satisfaction (Nielsen, 2012).

\section{RESULTS AND DISCUSSION}

Graphic 1 shows the results obtained in the pre-test, applied before training, and in the post-test applied after training. The scale used was from 0 points (lowest grade) to 20 points (highest grade). Of the 17 trainees who participated in this study, the majority was female, with only $18 \%$ male, aged between 21 and 38 years old, with mode being 22 years old (corresponding to $35 \%$ of the graduates) and 23 years old being the median. As shown in Graphic 1, all students scored a better result in the post-test. In all cases, there was an increase in the grades when comparing pre- with post-test. Regarding the IFS/BRC and ISO2200 courses, respectively, the highest absolute improvement was 12 points (MEA7) and 10 points (MEA2).

The lowest increase was, respectively, 4 points (Scholarship5 and Scholarship6) and 2 points (all scholarship holders except Scholarship4). The average of the increases obtained scored 7.6 points and 5.1 points. It was observed a higher increase in the score obtained by the group of master students than by the group of research fellows, for both course trainings. It should also be referred that in the post-test of the ISO22000 training, all trainees scored 20 points. 


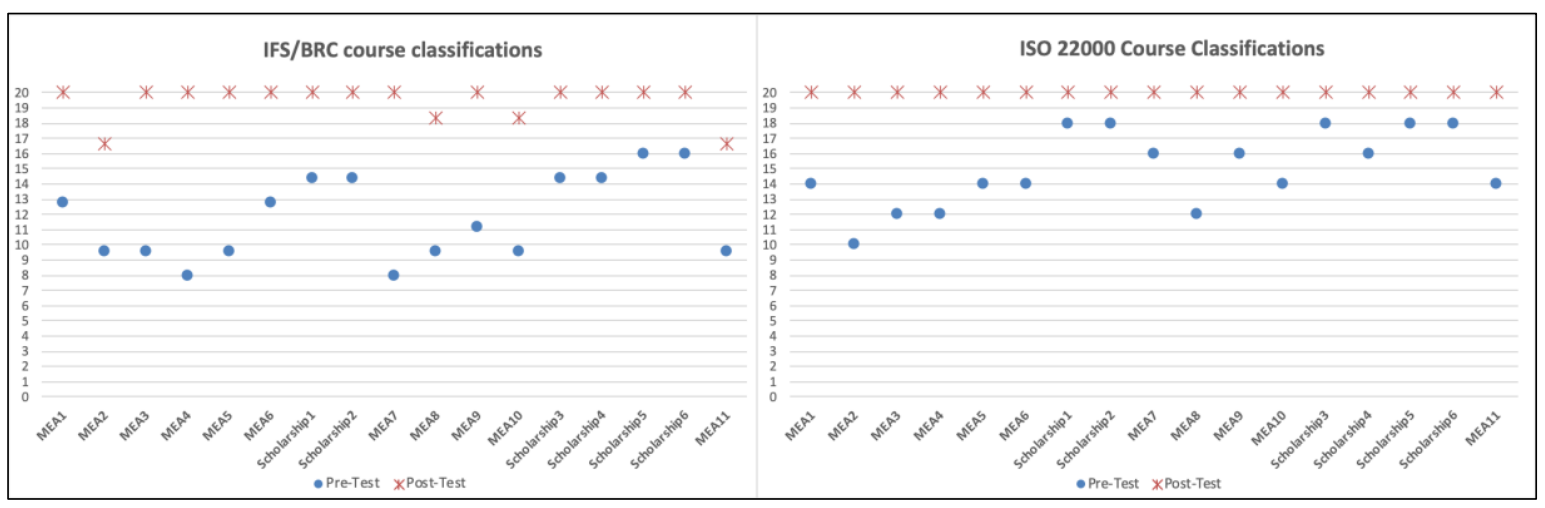

Graphic 1. Ratings of evaluations in training courses

Concerning both tests moments (pre- and post-), for the two training courses (Graphic 1), results show that the average rates of evaluations increased, 11.8 points to 19.4 points, for pre- and post-test, respectively, in the IFS/BRC course, and 14.9 points to 20 points, for pre- and post-test respectively, in the ISO22000 course. The data obtained are an evidence of the participants' learning improvement and their involvement in the learning process through the INTERNOVA platform.

At the end of the IFS/BRC training course, all the trainees who attended both tests (pre- and post-test) answered the other survey. Analysing the results obtained (Graphic 2), on a scale from 1 - Totally Disagree to 5 - Totally Agree, regarding the easiness of using the INTERNOVA platform, $94 \%$ of the trainees scored $5(56 \%)$ or $4(39 \%)$ that "the platform was easy to use". As well as the same percentage, $94 \%$, scored between $1(72 \%)$ and $2(22 \%)$ that "the platform was very complicated to use" (Graphic 2) which reinforces that for most users, this platform is easy to use. Thus, the same percentages showed students "had to learn a lot before being able to deal with this e-learning platform" and, accordingly, the majority (89\%) scored between $1(61 \%)$ and $2(28 \%)$ "needing help from a technician to be able to use it". Furthermore, $83 \%$ scored between $5(50 \%)$ and $4(33 \%)$ that "most people would learn to use this e-learning platform quickly".

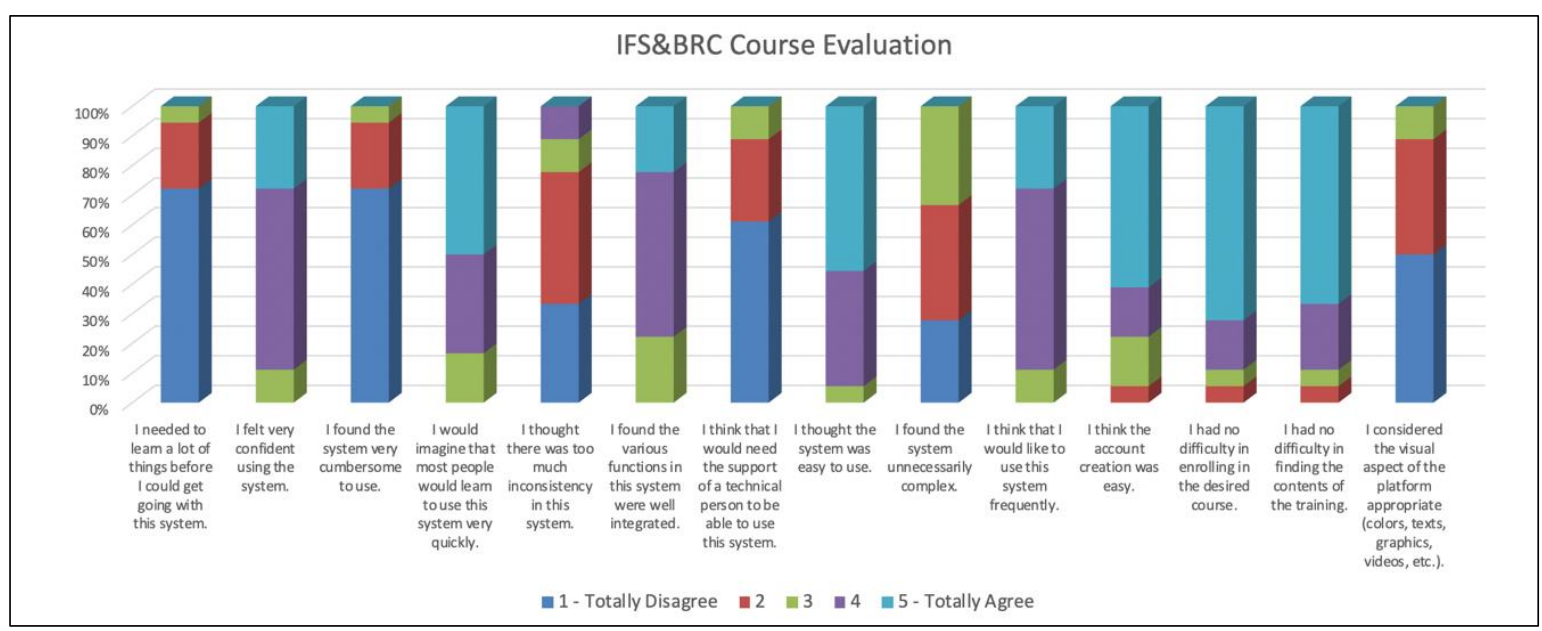

Graphic 2. Evaluation results of IFS/BRC training satisfaction survey

Concerning the question about "the visual aspect is adequate" the majority of participants scored it $1(50 \%)$ and $2(39 \%)$. Regarding the question about "who liked to use it frequently", the majority scored it $5(28 \%)$ and $4(61 \%)$. Furthermore, most of the participants $(67 \%)$ disagreed, having scored $1(28 \%)$ or $2(39 \%)$, about "the platform is unnecessarily complex", as well as 78\% disagreed, having indicated $1(33 \%)$ and 2 (44\%), for "the platform has many inconsistencies". About "the ease of access to training", namely the creation of an account and enrolment in training, there was no significant disagreement. Finally, regarding the IFS/BRC training course, a large majority of the participants (89\%) scored between $4(22 \%)$ and $5(67 \%)$ "who had no difficulty 
in finding the training content" and 78\% scored between $4(56 \%)$ and $5(22 \%)$ that "the various functionalities of this e-learning platform are well integrated".

Regarding ISO22000 course training (Graphic 3), only 59\% of the students who attended the course answered the second survey. It should be noticed that after the implementation of the previous course (IFS/BRC), some adjustments were made to the platform, taking into account the feedback obtained from the trainees. All participants scored between 4 and 5, that they "would like to use the platform more often", found the platform easy to use, that creating the account was easy, that most people would learn to use it quickly and did not experience difficulties in find training content. Most of the participants (90\%) scored "felt very confident using this e-learning platform" between 4 and 5 (Graphic 3 ).

In addition, all participants scored 1 and 2 to several questions, namely: "the need for help from a technician to be able to use this e-learning platform", " e-learning platform is very complicated to use", "having to learn a lot before being able to deal with this e-learning platform" and "visual aspect of the platform is adequate (colors, text, graphics, videos, etc.)". Although the trainees considered the visual aspect to be inadequate, they would like to use the platform frequently and felt confident in using it, which reveals some incongruity that may have resulted from the interpretation of the questions.

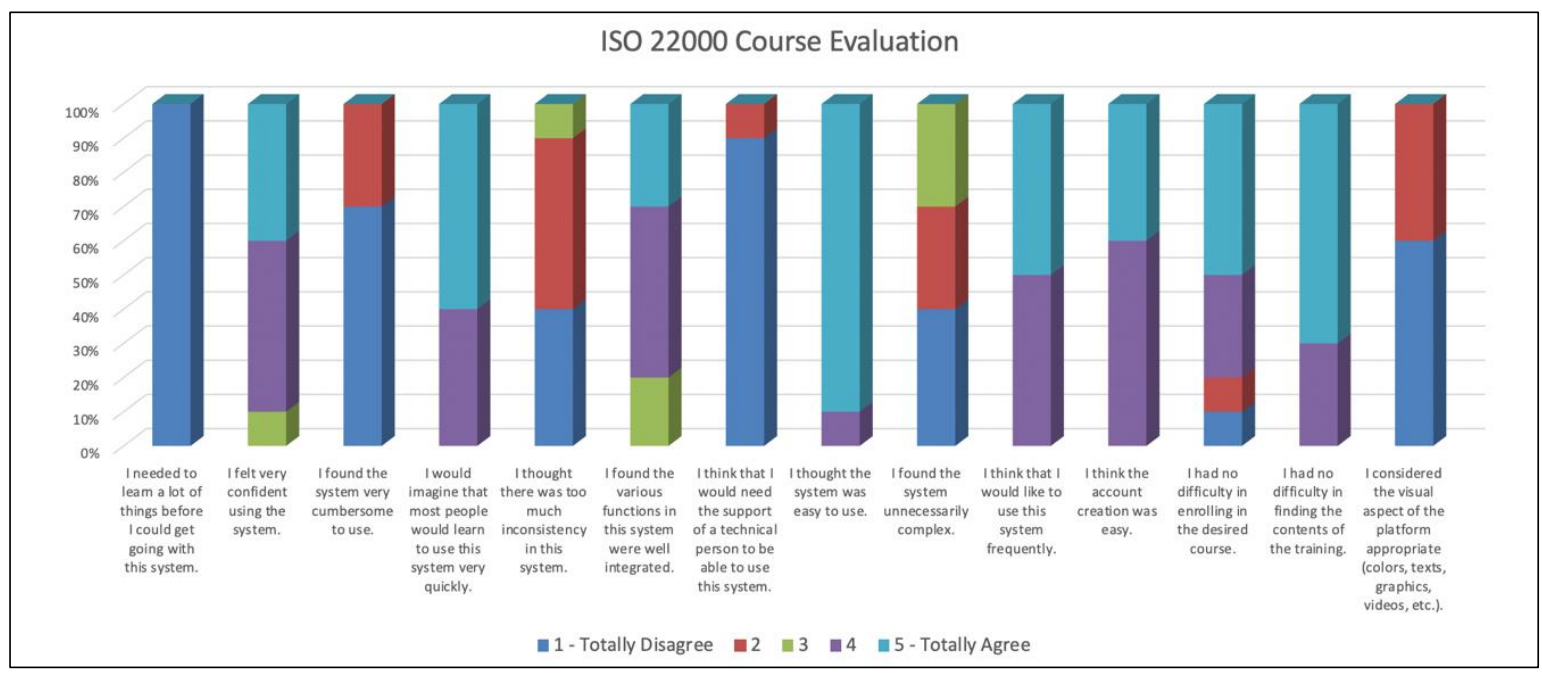

Graphic 3. Evaluation results of ISO22000 training satisfaction survey

In Graphic 4, it is possible to observe the results obtained from the usability analysis through the application of the SUS method considering the average of the normalized scores of the first 10 questions of the survey. From the results of the surveys carried out concerning both training courses, IFS\&BRC and ISO22000, were scored at 82.4 and 88.5 respectively. From the results of the questionnaires conducted in the context of the IFS\&BRC and ISO22000 training courses, a score of 82.4 and 88.5 respectively was obtained. In both training courses it was obtained a SUS value higher than 80.3, scored as "A", which corresponds to an excellent evaluation. With the results, it was concluded that the INTERNOVA platform, in both training courses, has an excellent usability (Bangor et al, 2009).

Specifically, considering the quality components indicated by Nielsen (2012), it appears that regarding both training courses, IFS\&BRC and ISO22000, the following values were obtained, respectively:

- Learning easiness - the average result of questions 3, 4, 7 and 10 from SUS are 85.4 and 96.3;

- Efficiency of the system - the average result of questions 5, 6 and 8 of SUS are 79.2 and 84.2;

- $\quad$ Ease of memorization - result of question 2 whose score are 79.2 and 77.5;

- System inconsistency - result of question 6 whose score are 75.0 and 82.5;

- Satisfaction - the average result of questions 1, 4 and 9 of SUS are 82.9 and 89.2. 


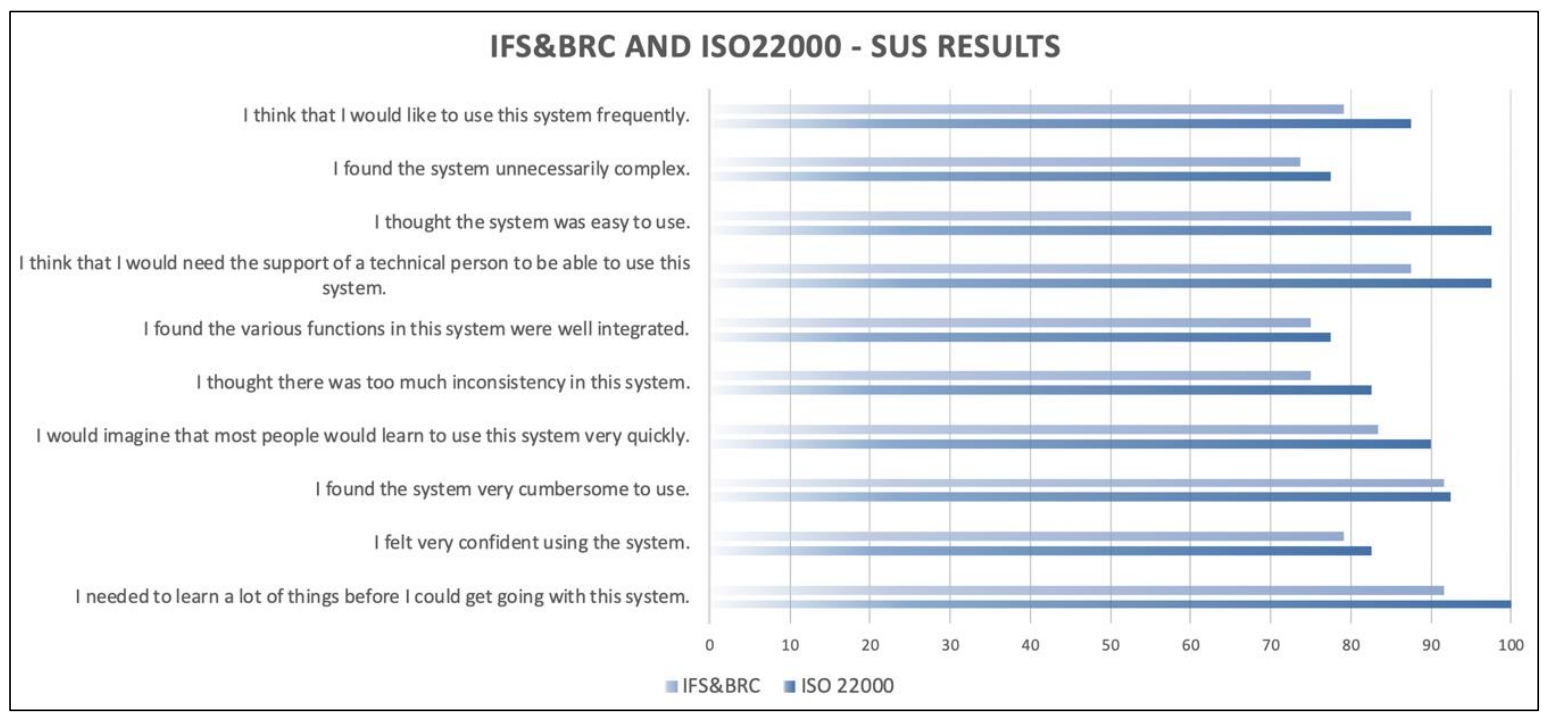

Graphic 4. SUS results of INTERNOVA platform survey

Regarding quality components of the platform, from the results obtained it was concluded that users have demonstrated easiness in learning how to use it, considering it efficient and easy to memorize, with low-level inconsistencies and a high degree of satisfaction.

\section{CONCLUSION}

The SUS score obtained for the INTERNOVA platform shows that this e-learning platform meets the usability requirements of the trainees who used it in an educational context. Approximately $90 \%$ of the participants involved in this study indicated that they liked using the INTERNOVA platform, considering it easiness and did not experienced difficulties in finding the training contents. These results lead to the conclusion that the students in the teaching-learning context used the platform as an online teaching tool.

Furthermore, through the online courses training available on the INTERNOVA platform it was concluded that all trainees acquired knowledge. From the data presented, it is believed that the use of a e-learning platform in an educational context is favourable to the construction of knowledge, that is, it was a driving force in the progress of teaching-learning process.

Thus, the present article reinforces the relevance of the development and use of LMS platforms in the educational context, corroborating with O'Donnell \& Sharp (2012) on the use of technology as facilitating tools in higher education seems to bring some advantages. Thus, it is the responsibility of higher education institutions to recommend well-designed curriculums, promoting teaching methodologies less focused on the teacher. In this way, teachers can improve their teaching practices, making them more appealing and attractive for students, to them to be more interested and more active in acquiring knowledge (Lobo \& Maia, 2015). On the other hand, the study here presented leads us to reflect on the relevance of using e-learning platforms in entrepreneurial context, enhancing a more flexible and more learner-centered learning environment.

\section{ACKNOWLEDGMENTS}

This work was supported by INTERREG V-A Espanha-Portugal (POCTEP) 2014-2020 (0437_INTERNOVAMARKET-FOOD_1_E) under the development of the project entitled "INTERNOVAMARKET-FOOD - Programa acelerador para aumentar a competitividade do sector alimentar da Galiza-Norte de Portugal". 


\section{REFERENCES}

Al-Samarraie, H., Teng, B., Alzahrani,A. \& Alalwan, N., 2018. E-learning continuance satisfaction in higher education: a unified perspective from instructors and students. Studies in Higher Education, Vol 43, No 11, pp 2003-2019

Araújo, I., 2014, Aprendizagem matemática no ensino superior: a influência da plataforma M@t-educar com sucesso. Tese de doutoramento. Aveiro: Universidade de Aveiro

Araújo, I. \& Faria, P. M., 2019. Potentialities of Using an Online Platform to Learn Mathematics in Engineering. In Proceedings of International Symposium on Project Approaches in Engineering Education: Preparing Teachers and Students for Challenging Times in Engineering Education / 16th Active Learning in Engineering Education Workshop - PAEE/ALE'2019, pp 268-275.

Bangor A, Kortum P, Miller, J., 2009. Determining what individual SUS scores mean: adding an adjective rating scale. Journal of Usability Studies, Vol 14, No 3, pp 114-123.

Brooke J., 1986. SUS - A quick and dirty usability scale. 1986. Disponível em https://hell.meiert.org/core/pdf/sus.pdf

Cidral, W., Oliveira, T., Felice, M. \& Aparicio, M., 2018. E-learning success determinants: Brazilian empirical study. Computers \& Education, Vol 122, pp 271-290.

Coutinho, C., \& Bottentuit Junior, J., 2007. Utilização da Plataforma Blackboard num Curso de Pós-Graduação da Universidade do Minho. In Dias, P., Freitas, C.V., Silva, B., Osósio, A., \& Ramos, A. (orgs.), Actas da V Conferência Internacional de Tecnologias de Informação e Comunicação na Educação: Desafios 2007/ Challenges 2007. pp. 305-313.

Daniela, L., Strods, R. \& Kalniņa, D., 2019. Technology-Enhanced Learning (TEL) in Higher Education: Where Are We Now? In M. Lytras, L. Daniela, A. Visvizi (Eds.), Knowledge-Intensive Economies and Opportunities for Social, Organizational, and Technological Growth, pp 12-24.

Dias, P., 2004. Processos de Aprendizagem Colaborativa nas Comunidades Online. In Dias, A., \& Gomes, M. (2004), E-Learning para E-formadores. TecMinho/Gabinete de Formação Contínua da Universidade do Minho, 19-31.

Dias, S., \& Diniz, J., 2010. Um estudo de caso no ensino superior - Avaliação de uma plataforma Moodle. Sistemas, Cibernética $e$ Informática: CISCI 2010. Florida. $\quad$ Disponível $\mathrm{em}$ https://www.iiis.org/CDs2010/CD2010CSC/CISCI_2010/PapersPdf/CA267FV.pdf

Junior, B., \& Coutinho, C., 2010. Recomendações para Produção de Podcasts e vantagens na utilização em Ambientes Virtuais de Aprendizagem. Revista Prisma.com. Vol. 6, 125-140.

Lbo, A. \& Maia, L., 2015. O uso das TICs como ferramenta de ensino-aprendizagem no Ensino Superior. Caderno de Geografia, Vol 25, № 44, pp 16-26.

MARCHIORI, L., MELO, W. \& MELO, J., 2011. Avaliação docente em relação às novas tecnologias para a didática e atenção no ensino superior. Avaliação: Revista da Avaliação da Educação Superior, Vol. 16, № 2, pp 433-443.

Moran, J., Masetto, M., Behrens, M., 2007. Novas tecnologias e mediações pedagógicas. 13ª. ed. São Paulo: Papirus.

Nielsen, J., 2012. Usability 101: Introduction to usability. Disponível em https://www.nngroup.com/articles/usability-101introduction-to-usability/

Nortvig, A., Petersen, A. \& Balle, S., 2018, A Literature Review of the Factors Influencing E-Learning and Blended Learning in Relation to Learning Outcome, Student Satisfaction and Engagement. Electronic Journal of e-Learning, Vol 16, $\mathrm{N}^{\circ} 1$, pp 46-55.

O,Donnell, E. \& Sharp, M., 2012, Students' Views of E-Learning: The Impact of Technologies on Learning in Higher Education in Ireland. In Moyle, K. \& Wijngaards, G., Student Reactions to Learning with Technologies: Perceptions and Outcomes, pp 204-225.

Ribeiro, J., 2010. Ambientes Virtuais de Aprendizagem no ensino superior: um estudo de caso sobre a utilização da plataforma Moodle. Disponível em http://www.fatecjp.com.br/revista/art-ed02-009.pdf

Ribeiro, N., 2012. Multimédia e tecnologias interativas (5a ed.). Lisboa, Portugal: FCA

Trinder, K., Guiller, J., Margaryn, A., Littlejohn, A. \& Nicol, D., 2008. Learning from digital natives: Bridging formal and informal learning. Higher Education Academy. 